\title{
Can Tanzania's adaptation measures prevent future maize yield decline? A simulation study from Singida region
}

\author{
Johanna Volk ${ }^{1}$ (D) Christoph Gornott ${ }^{2,3} \cdot$ Stefan Sieber $^{4,5} \cdot$ Marcos Alberto Lana $^{6}$
}

Received: 31 January 2021 / Accepted: 10 July 2021 / Published online: 27 September 2021

(c) The Author(s) 2021

\begin{abstract}
Cereal crop production in sub-Saharan Africa has not achieved the much-needed increase in yields to foster economic development and food security. Maize yields in the region's semi-arid agroecosystems are constrained by highly variable rainfall, which may be worsened by climate change. Thus, the Tanzanian government has prioritized agriculture as an adaptation sector in its intended nationally determined contribution, and crop management adjustments as a key investment area in its Agricultural Sector Development Programme. In this study, we investigated how future changes in maize yields under different climate scenarios can be countered by regional adjusted crop management and cultivar adaptation strategies. A crop model was used to simulate maize yields in the Singida region of Tanzania for the baseline period 1980-2012 and under three future climate projections for 2020-2060 and 2061-2099. Adaptation strategies to improve yields were full irrigation, deficit irrigation, mulch and nitrogen addition and another cultivar. According to our model results, increase in temperature is the main driver of future maize yield decline. Increased respiration and phenological development were associated with lower maize yields of 16\% in 2020-2060 and 20\% in 2061-2099 compared to the 1980-2012 baseline. Surprisingly, none of the management strategies significantly improved yields; however, a different maize variety that was tested as an alternative coping strategy performed better. This study suggests that investment in accessibility of improved varieties and investigation of maize traits that have the potential to perform well in a warmer future are better suited for sustaining maize production in the semi-arid region than adjustments in crop management.
\end{abstract}

Keywords Maize $\cdot$ Climate change $\cdot$ Adaptation $\cdot$ Model $\cdot$ Tanzania $\cdot$ NDC

Communicated by Woonsup Choi

Johanna Volk

johanna.volk@uni-hohenheim.de

Christoph Gornott

gornott@pik-potsdam.de

Stefan Sieber

stefan.sieber@zalf.de

Marcos Alberto Lana

marcos.lana@slu.se

1 Department of Management of Crop Water Stress in the Tropics and Subtropics, Faculty of Agricultural Sciences, University of Hohenheim, Stuttgart, Germany

2 Department of Agroecosystem Analysis and Modelling, Faculty of Organic Agricultural Sciences, University of Kassel, Kassel, Germany
3 Potsdam Institute for Climate Impact Research (PIK), Member of the Leibniz Association, Potsdam, Germany

4 Leibniz Centre for Agricultural Landscape Research, Müncheberg, Germany

5 Department of Agricultural Economics, Faculty of Life Sciences, Humboldt University of Berlin, Berlin, Germany

6 Department of Crop Production Ecology, Faculty of Natural Resources and Agricultural Sciences, Swedish University of Agricultural Sciences (SLU), Uppsala, Sweden 


\section{Introduction}

Smallholder agriculture is vital for the provision of food and incomes for people in sub-Saharan Africa (Cooper et al. 2008; OECD/FAO 2016). Crop farming dominated by cereal production is an important component of food availability, which, in turn, is crucial for food security, poverty reduction and economic development (FAO 2006; Diao et al. 2010; Macauley and Ramadjita 2015). In particular in semi-arid agroecosystems, smallholder farmers suffer considerable production shortfalls due to unreliable rainfall, lack of irrigation infrastructure and low soil fertility (Cooper et al. 2008; Burney et al. 2013; Hillocks 2014).

In Tanzania, crop production accounts for $32 \%$ of the country's gross domestic product (The World Bank 2018) and is dominated by maize (Zea Mays L.) (Thurlow and Wobst 2003), a staple food supplying up to $33 \%$ of people's daily caloric consumption (USAID 2010; Pauw and Thurlow 2011). Maize production in the country is nearly exclusively rain-fed as only $3 \%$ of the total planted area is irrigated (URT 2016). Thus, maize production is highly dependent on weather conditions, which hampers a reliable prediction (Gowing et al. 2003; Rowhani et al. 2011). Therefore, climate change has been identified as a threat to Tanzania's maize production due to associated increases in temperature and changes in rainfall patterns (Adhikari et al. 2015; Rao et al. 2015). Consequently, current maize yields are projected to decline at local level by up to $37 \%$ by 2050 (Arndt et al. 2012; Msongaleli et al. 2015).

In response to projected yield declines, Tanzania lists adaptation strategies in the agriculture sector as a priority in its intended nationally determined contribution (INDC) (URT 2015). The nationally determined contribution (NDC) is the outlines of the 2015 Paris Climate Agreement signatories for their post-2020 mitigation and adaptation action (UNFCCC 2019). Two of the four contributions in the agricultural sector Tanzania is planning to implement are: (a) upscaling the level of improvement of agricultural land and water management and (b) increasing yields through, amongst other measures, climate smart agriculture (CSA) (URT 2015).

These contributions are echoed in Tanzania's Agricultural Sector Development Programme that has entered into its second phase (ASDP II) from 2017/18 to 2027/28 (URT 2017a). Irrigation infrastructure development and promotion of conservation agriculture (CA) and CSA are listed as priority investment areas to support the agricultural sector to counter climate change impacts. One cornerstone of conservation in smallholder agriculture is covering soil with mulching material (Shetto and Owenya 2007), a measure that is also part of Tanzania's Climate-Smart Agriculture Guideline (URT 2017b). However, there is a lack of information on how the suggested future adaptation options might influence maize production at regional level. Tanzania has various climatic regions, soils and growing conditions (Hecklau 1978; Chorowicz 2005; Thornton et al. 2010). Thus, the national adaptation guidelines must be tested and adapted mainly at regional level.

One effective tool for analysing future growing conditions and potential adaptation measures are crop simulation models (CSMs) coupled with climate projections. CSMs are used to estimate agricultural production as a function of weather parameters, soil conditions and crop management (Murthy 2004). Considering the anticipated decline in cereal production in Tanzania due to climate change, crop models can be used to study the sensitivity of agricultural systems to changes in climate conditions. They can also be used to study effects on future production and benefits of adaptation/management measures (Thorburn et al. 2015) by linking them to climate projections (Fischer et al. 2005). For example, a commonly used CSM for maize is the CropEnvironment-Resource-Synthesis (CERES) maize module (Jones et al. 1986), which is part of the well-established Decision Support System for Agrotechnology Transfer (DSSAT) (Jones et al. 2003).

On the other hand, as atmospheric concentrations of carbon dioxide are set to drive future climatic conditions, climate projections consider scenarios of varying emission levels on general circulation models (GCMs) (Pachauri and Meyer 2014). Scenarios indicating different emission levels are called representative concentration pathways (RCPs) (Moss et al. 2010). All GCMs project a warmer climate for the East African region in the twenty-first century, but rainfall projections are highly uncertain. Most models project that changes in rainfall amounts will not surpass those from the past century, whereas others indicate increases and decreases in mean annual rainfall (Hulme et al. 2001; Washington and Pearce 2012; Niang et al. 2014).

A climate change adaptation policy is needed for Tanzania where rain-fed maize production is widely practised. But there is limited information in relevant regions to guide decision-making before the allocation of scarce financial resources for adaptation, with consequences on food security. The Singida region in Tanzania is a suitable test case as maize production occurs on more than 33\% of the total cultivated area (URT 2012), and maize is a priority crop for investments under the ASDP II (URT 2017a).

In this study, we are interested in understanding future changes in maize yields using the DSSAT CERES model under current and future climate scenarios (i.e., output from five GCMs under three RCPs) and for alternative crop management measures and cultivar adaptation options in Singida. We aim to give insights about potential physiological and phenological mechanisms by evaluating several plant stress parameters including water and nitrogen. Specifically, our objectives are to (a) identify patterns and trends of mean temperature and precipitation in 
climate projections for 2020-2060 and 2061-2099, and compare them with the maize growing season of the 1980-2012 baseline period; (b) use a calibrated and validated crop model to project maize yields under future climate conditions for Singida; (c) use crop model output data to make conclusion about potential yield-reducing mechanisms; (d) investigate the effect of management and cultivar adaptation on future maize yields; and (e) give recommendations on potential adaptation strategies.

\section{Methodology}

\section{Study area}

The study area is situated in the north of Singida region in Tanzania within latitude $3^{\circ} 5^{\prime}$ to $5^{\circ} 5^{\prime}$ South and longitude $33^{\circ} 9^{\prime}$ to $35^{\circ} 3^{\prime}$ East and encompasses the five districts of Mkalama, Iramba, Singida Rural, Singida Urban and Ikungi (Fig. 1). The region occupies the northern part of the Central Plateau, which lies between the two branches of the East African rift system and has an elevation of 1200-1500 m above sea level (Chorowicz 2005; URT 2017d).

Climatically, Singida lies in the semi-arid Central Tanzania (Hecklau 1978; Lema and Majule 2009) with annual rainfall ranging $500-800 \mathrm{~mm}$ in a unimodal rainy season from October to May, which is interrupted by a dry season from June to September (Basalirwa et al. 1999; URT 2017d). Mean monthly temperatures and rainfall in the study area during the growing seasons of 1980-2012 (baseline) are shown in Fig. 2. Mean cumulative rain is $693 \mathrm{~mm}$ and mean average temperature is $23^{\circ} \mathrm{C}$.

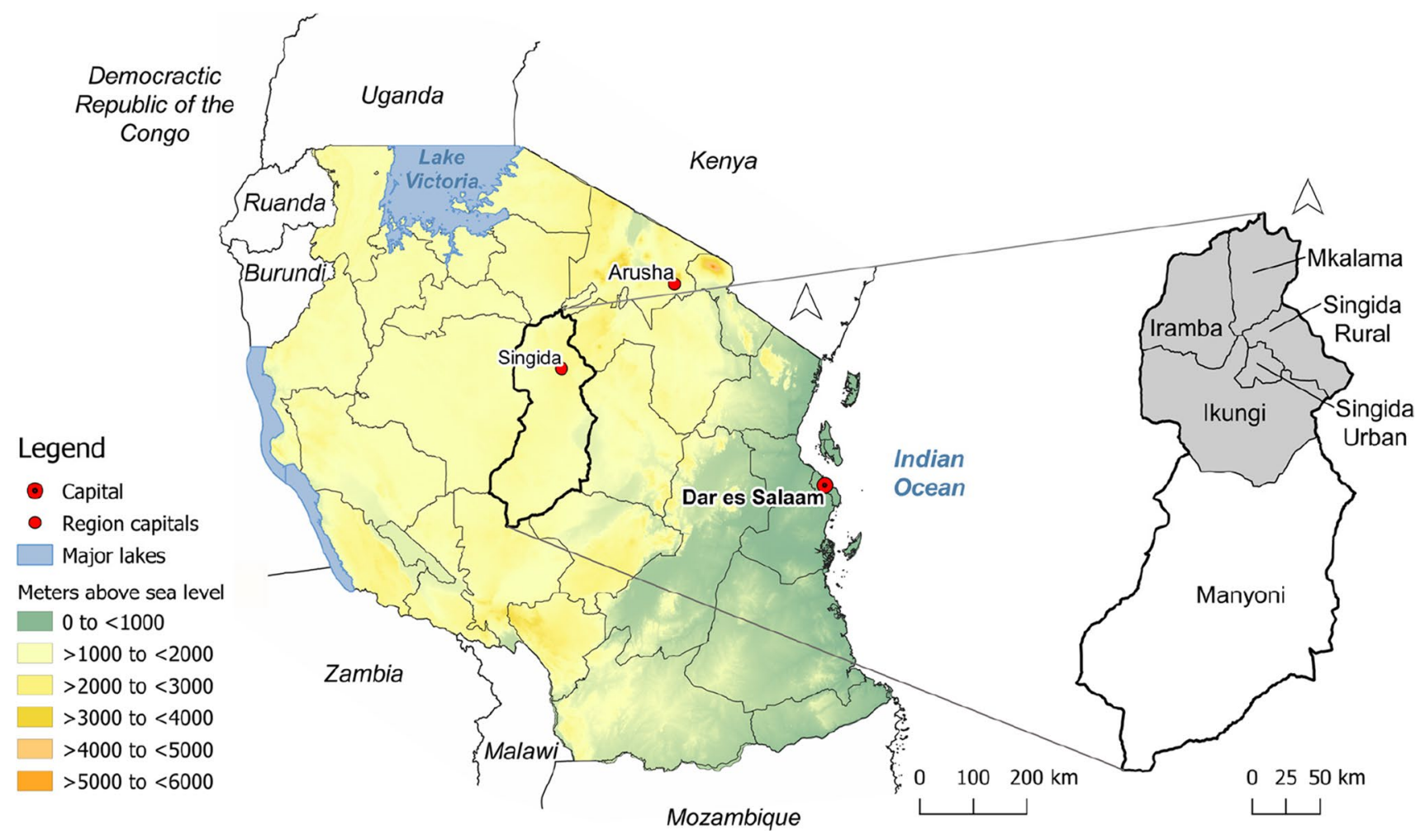

Fig. 1 Location of study area

Fig. 2 Mean monthly temperatures and rainfall in the study area during the 1980-2012 growing season with $95 \%$ confidence intervals (data source: WFDEI (Weedon et al. 2014))
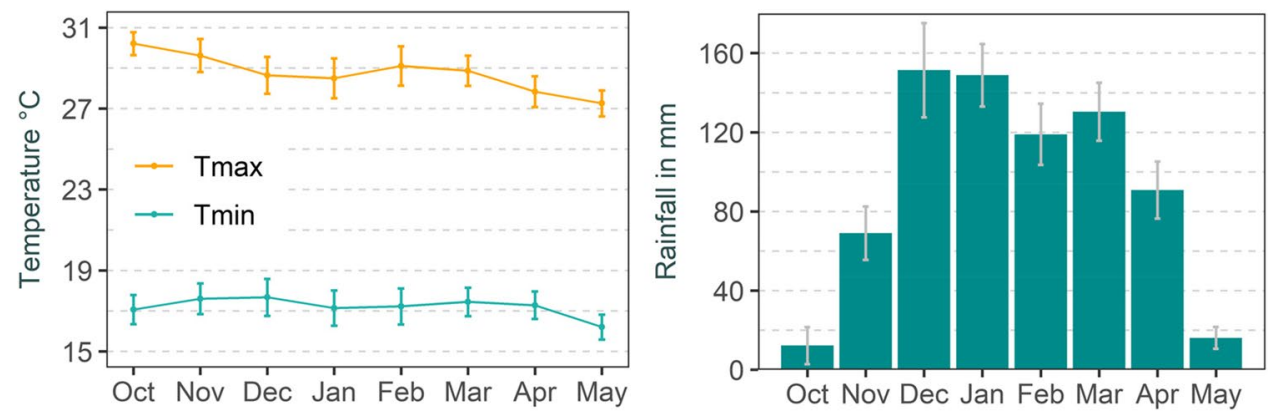
Most of the annual cropland is concentrated in the northern part of the Central Plateau; thus, we focus our study on the five northern districts (Fig. 1). This information on the region's potential cropland area was derived from a 30-m resolution land cover map (RCMRD 2015).

The soil in the study area is dominated by Cambisols and Vertisols (Dijkshoorn and van Engelen 2003). Cambisols of the (sub-)tropics are suitable for agricultural use due to high mineral content and good nutrient storage capacity (URT 2006; Zech et al. 2014), but Vertisols are limited by a narrow soil moisture range (Zech et al. 2014; FAO 2015).

\section{Crop model}

\section{Climate and soil data}

Climate data for the crop simulation at daily resolution were obtained from the WFDEI dataset for the baseline period (Weedon et al. 2014), while future climate data was based on projections. For the baseline 1980-2012, average monthly minimum and maximum temperatures and rainfall and mean cumulative rainfall were calculated.

Daily future climate data at a spatial resolution of $0.5^{\circ} \times 0.5^{\circ}(\sim 50 \mathrm{~km})$ derived from the Intersectoral Impact Model Intercomparison Projects (ISI-MIP), a bias corrected database (Hempel et al. 2013; Warszwaski et al. 2014), were obtained for three RCP scenarios (i.e., RCP 2.6 as low, RCP 4.5 as medium and RCP 8.5 as high emission scenario). The RCPs define temporal targets of radiative forcing (i.e., the change in the balance between incoming and outgoing radiation to the atmosphere caused by changes in greenhouse gas concentrations) up to the year 2100 (Moss et al. 2010). Daily RCP data contained eleven parameters for the time span of 1950 to 2099 that were derived from five GCMs: GFDL-ESM2M (Dunne et al. 2013), HadGEM2-ES (Jones et al. 2011), IPSL-CM5A-LR (Hourdin et al. 2013), MIROC-ESM-CHEM (Watanabe et al. 2011) and NorESM1-M (Iversen et al. 2013).

For the future scenarios, ensembles were created by averaging minimum and maximum temperatures $\left(\mathrm{T}_{\min }\right.$ and $\mathrm{T}_{\max }$ ) and precipitation data of all GCMs for each of the three RCPs to account for the range uncertainties of individual models (Randall et al. 2007; Luhunga 2017). The data were split into two time periods: 2020-2060 and 2061-2099.

Soil data for the crop simulation model were taken from the global high-resolution soil profile database for crop modelling applications at $0.1^{\circ} \times 0.1^{\circ}(\sim 10 \mathrm{~km})$ resolution (Han et al. 2015). Each grid profile contains information on twelve soil parameters per soil layer, e.g. organic carbon, cation exchange capacity and wilting point. Grids were combined to generate polygons with unique combinations of soil and weather.

\section{Yield data and adaptation options}

Maize yields for past and future climate as well as effects of different adaptation options were simulated in DSSAT version 4.7 (Hoogenboom et al. 2017). The crop simulation model used for estimating yields was CERES maize (Jones et al. 1986).

Maize yield simulations were run for years 1980-2012 to obtain the baseline and for the period of 2020-2099 under future RCP scenarios. The model was run for each combination of GCM and RCP; yield and other data were aggregated afterwards. The beginning of maize simulations was set for 3 months before the planting date to obtain a more realistic measure of the soil water balance at sowing (Lana et al. 2017). All planting dates were set for the 15th of December. Seeds were sown in rows at $75-\mathrm{cm}$ spacing, $5 \mathrm{~cm}$ of depth, yielding a density of three plants per $\mathrm{m}^{2}$. We use in the model the $H 612$ cultivar, a single-cross hybrid first released in Kenya and a popular maize variety in Tanzania (Johnson et al. 1980; Mfwango et al. 2018), already validated in DSSAT (Gude 2016; Mfwango et al. 2018). The model was calibrated by comparing the model output for the 1980-2012 yield baseline with available observed maize yields in the research area (URT 2004, 2005, 2010, 2017c). Five kilogramme of nitrogen per hectare was set to be broadcasted and incorporated at $10-\mathrm{cm}$ depth as the common management practice by smallholder farmers includes minimum use of fertilizer and no irrigation (URT 2012; Mourice et al. 2014; Msongaleli et al. 2015). Thus, the model did not include irrigation. Finally, the harvest dates were set 2 weeks after physiological maturity of maize as calculated by the model. The yield output of each polygon for the future periods under the five GCMs was averaged for each RCP and divided into the two time periods of 2020-2060 and 2061-2099.

To test four adaptation options for maize under future climate as projected by the GCMs, the management input was modified to simulate deficit irrigation (DI), full irrigation (FI), mulching (MU) and increased nitrogen fertilization $(15 \mathrm{~N})$. First, for deficit irrigation, the total irrigation amount was set at $20 \%$ of average rainfall during the maize growing period of the 1980-2012 baseline, resulting in a total supplementary irrigation amount of $93 \mathrm{~mm}$. Deficit or supplementary irrigation scheduling is often done according to threshold values such as percentage of soil water content or crop evapotranspiration (Ezekiel and Igbadun 2018; Sharda et al. 2019); however, a growth stage-based scheduling was chosen as this approach can be easily applied onfarm in Tanzania (Eyshi Rezaei and Gaiser 2017). Because it is widely known that water stress during the reproductive 
growth stages of maize, especially the flowering stage from tassling to silking, has a negative effect on yield (Igbadun et al. 2008; Comas et al. 2019), it is common for supplementary or deficit irrigation to allocate more of the available irrigation water to the reproductive stage, and to do so in shorter intervals (Moradi et al. 2013; Eyshi Rezaei and Gaiser 2017; Greaves and Wang 2017). Thus, a 20:80 split of irrigation water between the vegetative and reproductive stages was chosen (Saseendran et al. 2008). The irrigation interval was set at 10 days in the vegetative growth stages and 5 days in the reproductive growth stages, resulting in $9.3 \mathrm{~mm}$ applied at ten irrigation events. Nevertheless, no irrigation was applied during the first 24 days after sowing (DAS) as suggested by Greaves and Wang (2017), as sowing is done in accordance with the beginning of the rainy season.

Second, full irrigation with automatic irrigation scheduling based on soil water depletion was applied to simulate a scenario without water stress. Automatic irrigation was adopted starting when $50 \%$ of the crop available water in the upper $0.3 \mathrm{~m}$ of the soil profile was depleted. This resulted in an average of a single irrigation event (minimum 0 , maximum 17 events) of $23.5 \mathrm{~mm}$ across time periods and RCPs. Furrow irrigation was chosen for both deficit and full irrigation as a low-cost technique (Sepaskhah and AfsharChamanabad 2002) with the application efficiency set at 60\% (Brouwer et al. 1989).

Third, mulching with crop residues to improve yields was tested. Nevertheless, this is not widely practised in Tanzania because crop residue is often left for livestock herds to graze or removed from the field by burning (Shetto and Owenya 2007). However, studies show that this measure has a high potential for climate change adaptation in reducing soil evaporation and temperature and releasing nutrients through decomposition (Qin et al. 2015; Liu et al. 2017). For the future simulations, $3000 \mathrm{~kg}$ per hectare of dry matter maize residue (Shemdoe et al. 2009) was set to be applied at planting, as suggested by Corbeels et al. (2016). The residue nutrient concentration levels of $0.66 \%$ nitrogen, $0.07 \%$ phosphate and $0.30 \%$ potassium were adopted from Bidogeza et al. (2012).

Last, to simulate increased nitrogen fertilization, the amount was tripled to $15 \mathrm{~kg}$ nitrogen per hectare at unchanged application method. Furthermore, we tested whether a different cultivar would better perform under future climate. Therefore, the Situka cultivar was chosen, an open-pollinated maize variety with early maturity, tolerance to low nitrogen levels and a yield potential of 4-6 tons per hectare (Mourice et al. 2014; Msongaleli et al. 2015). Situka has been calibrated and validated for Tanzanian field conditions (Mourice et al. 2014; Lana et al. 2017).

\section{Stress parameters and days to harvest}

To explore the physiological and phenological processes potentially triggered by climate change, daily data on water stress, excess water stress and nitrogen stress were extracted from the DSSAT output and evaluated for the two future periods under baseline management settings. The same was done for the number of days to harvest, where the future periods and the baseline were compared.

\section{Statistical analysis}

Climate and yield data were analysed in ' $\mathrm{R}$ ' ( $\mathrm{R}$ Core Team 2017). In preparation for trend analysis, rainfall and $T_{\min } / T_{\max }$ data were tested for normality in frequency distribution with the Shapiro-Wilk test (Shapiro and Wilk 1965) at a significance threshold of 5\% (Bahrenberg and Giese 1975). For the baseline period, regression and correlation analyses were used to test for trends in rainfall sums, $\mathrm{T}_{\min }$ and $\mathrm{T}_{\max }$ means and standard deviations of the parameters as a measure of dispersion (Bahrenberg and Giese 1975). The direction and strength of the trend was determined with the Pearson-product-moment correlation (Zimmermann-Janschitz 2014).

Monthly deviations of projected climate parameter data from the baseline were calculated using the differences between monthly means of future time periods and baseline values. These differences were tested for statistical significance using the Welch two-sample $t$ test (Welch 1938) or the non-parametric Mann-Whitney $U$ test (Rasch et al. 2010) depending on the outcome of the Shapiro-Wilk test. The null hypothesis, assuming no differences between baseline and projection climate means, was rejected at $5 \%$ probability of error (Bahrenberg and Giese 1975; Rasch et al. 2010).

To determine whether maize yields projected for the future time periods are significantly different from baseline yields, and whether yields projected for the four adaptation treatments differ significantly from those under baseline management, an analysis of variance (ANOVA) was computed, followed by Tukey's HSD as post-hoc test. The null hypothesis of no significant difference was rejected at alpha $5 \%$.

\section{Results}

\section{Patterns and trends in climate projections}

Across RCPs, mean cumulative rainfall during the growing period in 2020-2060 did not deviate significantly from cumulative rainfall during the baseline period. During the growing season of 2061-2099, cumulative precipitation increased by $108 \mathrm{~mm}$ and $144 \mathrm{~mm}$ for RCP4.5 and RCP8.5, respectively, though only the increase under RCP8.5 was significant.

The monthly precipitation deviations are more heterogenous (Fig. 3). While none of the changes to the baseline period are statistically significant, noticeable remains the negative 
Fig. 3 Growing season mean monthly rainfall deviations from the baseline (set to zero, solid line) for 2020-2060 (a) and 2061-2099 (b) using RCPs 2.6, 4.5 and 8.5
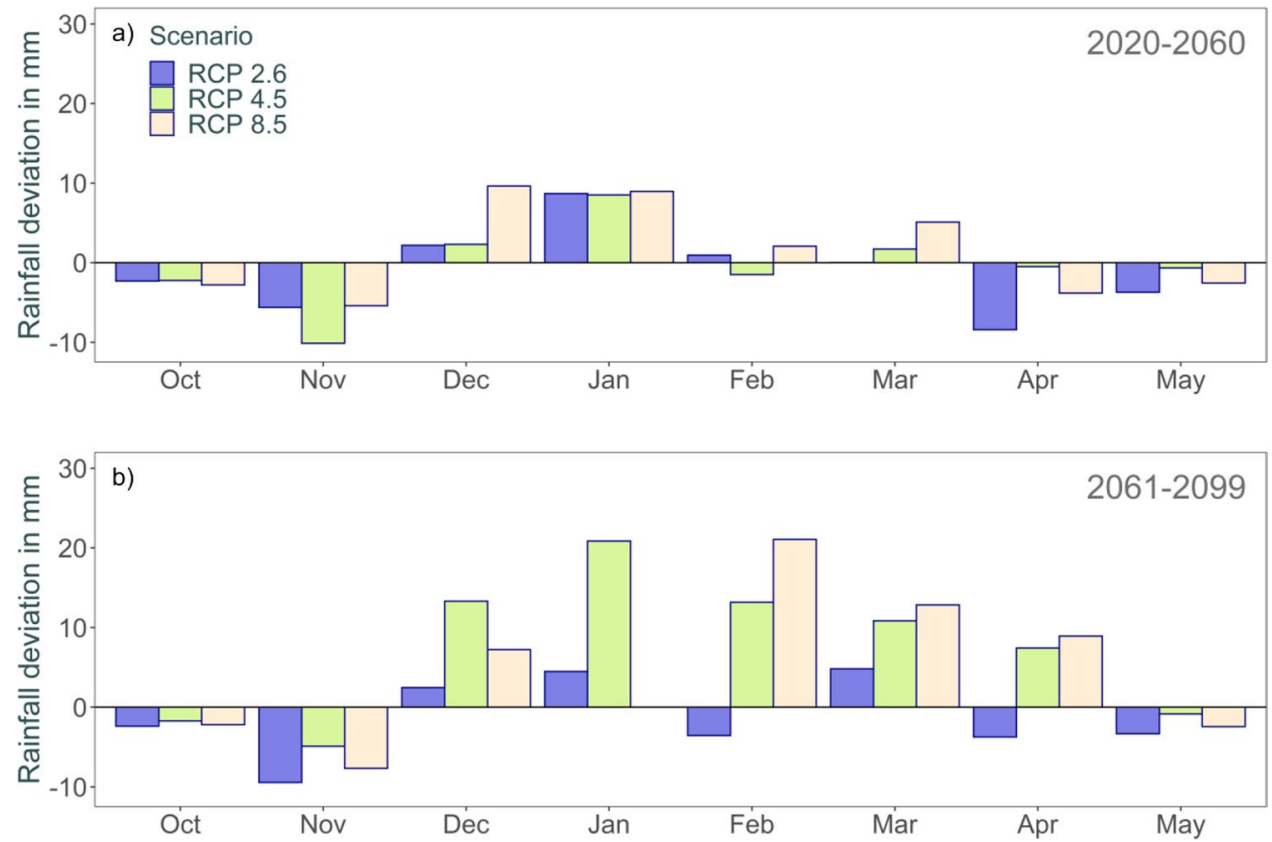

Table 1 Growing season mean minimum and maximum temperature deviations $\left(\mathrm{T}_{\min }\right.$ and $\mathrm{T}_{\max }$ ) from baseline to 2020-2060 and 20612099 for RCPs $2.6,4.5$ and 8.5

\begin{tabular}{llll}
\hline $2020-2060$ & RCP 2.6 & RCP 4.5 & RCP 8.5 \\
$\mathrm{~T}_{\min }$ & +1.3 & +1.8 & +1.9 \\
$\mathrm{~T}_{\max }$ & +1.1 & +1.5 & +1.7 \\
$2061-2099$ & RCP 2.6 & RCP 4.5 & RCP 8.5 \\
$\mathrm{~T}_{\min }$ & +1.4 & +2.5 & +4.0 \\
$\mathrm{~T}_{\max }$ & +1.2 & +2.0 & +3.7 \\
\hline
\end{tabular}

nature of monthly deviations for the beginning and end of the growing season, with an increase in the middle.

Temperatures in the projections showed a positive deviation from the baseline throughout the growing season. Generally, temperature increased from RCP 2.6 to RCP 4.5 to RCP 8.5 and between the first and second future simulation period (Table 1). Null hypotheses for the $u$ test and $t$ test were rejected for both $\mathrm{T}_{\min }$ and $\mathrm{T}_{\max }(p$-value $<0.05)$, indicating significant differences of temperature between the baseline and future periods and scenarios.

Daily maximum temperatures for much of the simulation period are higher for the future projections compared to the baseline (Fig. 4). Nevertheless, even for the RCP 8.5 scenario and the 2061-2099 period, mean $\mathrm{T}_{\max }$ did not cross the $35^{\circ} \mathrm{C}$.

\section{Maize yield simulation}

\section{Baseline and future yields in Singida region}

On the basis of the baseline and future climate data, we modelled the maize yields for the Singida region. The modelled yields for the baseline period of 1980-2012 ranged from a minimum of $0.6 \mathrm{t} \mathrm{ha}^{-1}$ to maximum $1.9 \mathrm{tha}^{-1}$. The mean for the study area is $1.7 \mathrm{tha}^{-1}$ (Fig. 5, Supplementary material Fig. A), well representing available average measured yield of $1.6 \mathrm{t} \mathrm{ha}^{-1}$ reported in Singida between 2003 and 2010 (URT 2017c). However, the baseline yields are slightly higher than those outlined in the agricultural basic data where the average for the region lies at $1.1 \mathrm{tha}^{-1}$ between 1996 and 2009 (URT 2004, 2005, 2010).

Averaged over the study area, mean future maize yields for all RCPs are significantly lower than for the baseline (Fig. 5, Supplementary material Fig. B). Negative deviations from the baseline average increase from RCP2.6 to RCP8.5 for both future time periods with the exception of RCP4.5 and RCP8.5 in the 2020-2060 period. However, there was no statistically significant difference within RCPs for the two future periods, except for RCP8.5, where maize yields were significantly lower for the 2061-2099 period ( $p$-value $<0.05)$. Expressed as percentages, maize yields across the research area decline on average by $16 \%$ during 2020-2060 and by $20 \%$ during 2061-2099, with a range of +20 to $-27 \%$ for the first period and +21 to $-39 \%$ for the second period.

\section{Management and cultivar adaptation as strategies for future periods}

The projected decreasing maize yields caused by climate change require adaptation measures to compensate this loss. Our results show that maize yields for both future periods are projected to decline from the baseline yields, independent from the tested adaptation measures in both 
Fig. 4 Mean daily maximum temperature for the 1980-2012 baseline and for 2020-2060 (a) and 2061-2099 (b) under the RCPs 2.6, 4.5 and 8.5
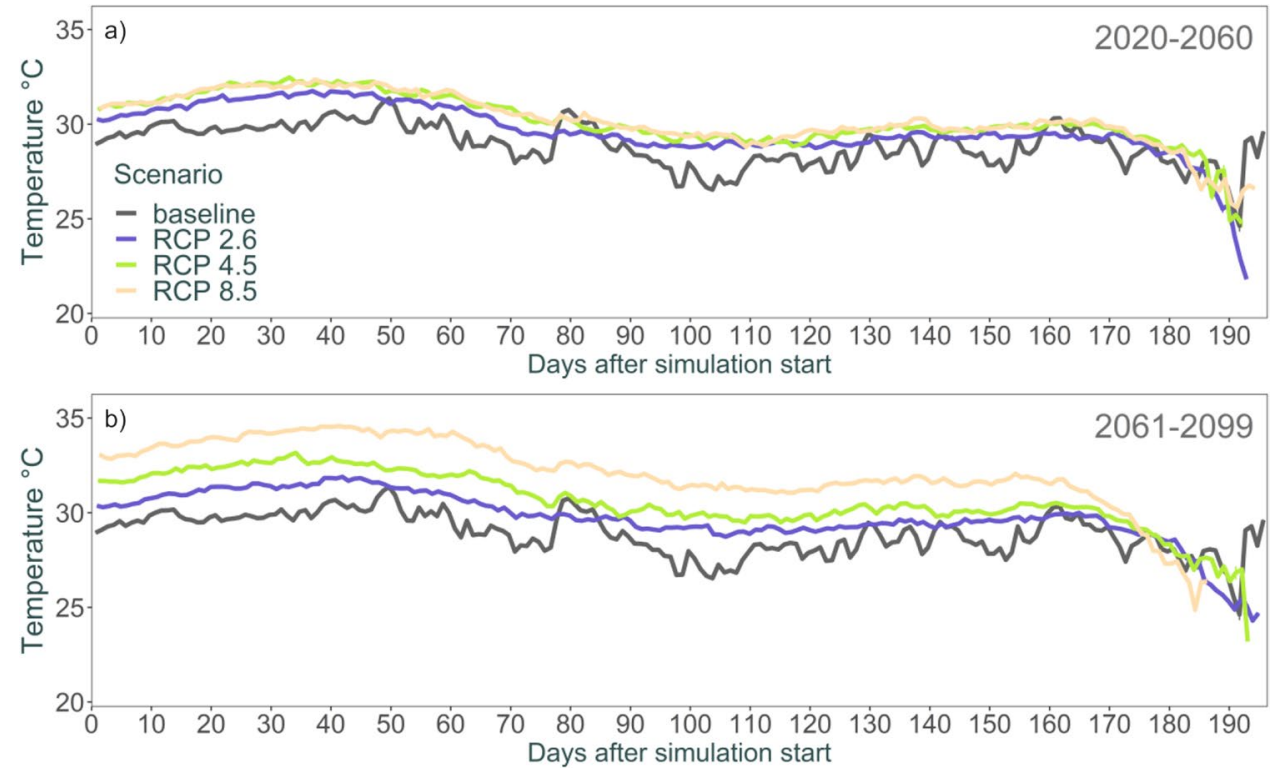

Fig. 5 Mean yield (H612 cultivar) for the 1980-2012 baseline and for 2020-2060 and 20612099 under the RCPs 2.6, 4.5 and 8.5 ; boxes represent mean and standard deviations, lines minimum and maximum values; stars show observed yields of $1.6 \mathrm{t} \mathrm{ha}^{-1}$ (URT 2017c) and 1.1 $\mathrm{t} \mathrm{ha}^{-1}$ (URT 2004, 2005, 2010); different letters indicate statistically different yields $(p<0.05)$

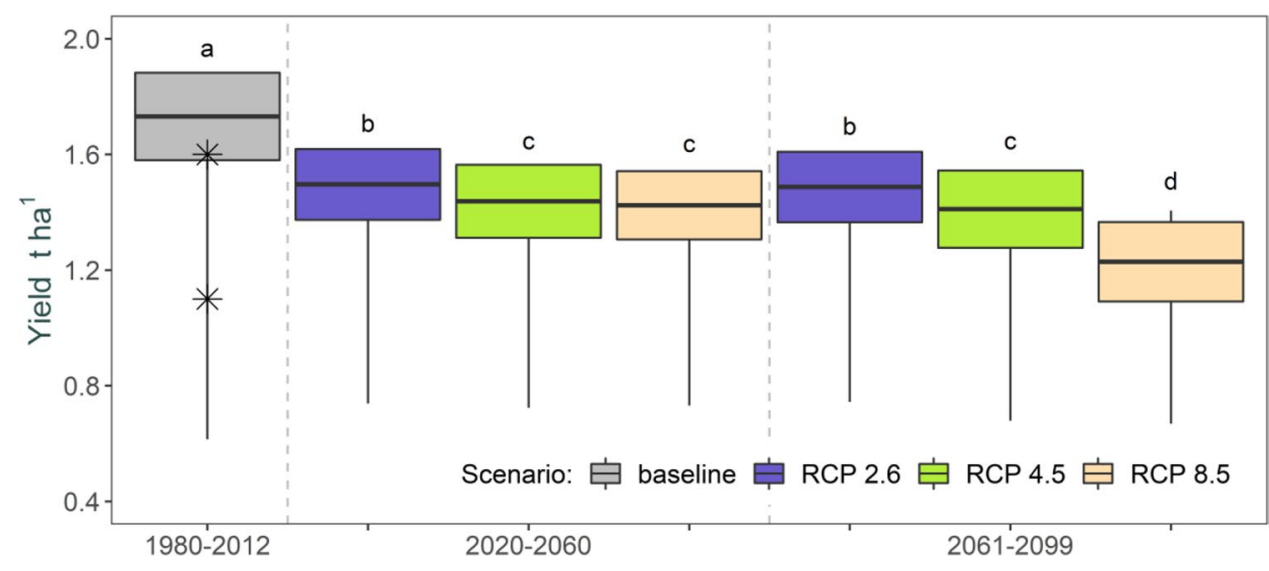

simulation periods (Fig. 6 showing 2020-2060). Within each RCP projection, there is no effect of either irrigation, mulching or additional fertilizer on the mean yield, i.e., all five treatments share at least one common letter for boxes of the same colour (Fig. 6). One exception is deficit irrigation under the RCP 8.5 scenario in 2020-2061 which slightly decreased mean yield compared to the baseline management setting. Only in some parts of the research area, maize yields are projected to increase more under enhanced nitrogen fertilization $(15 \mathrm{~N})$ and mulch application (MU), compared to unchanged management (NT).

Compared to the H612 cultivar, Situka produces higher yields for all projections in 2020-2099 under baseline management settings (Fig. 7). While the maximum absolute reduction in yield is steeper for Situka, even under the RCP8.5 scenario in 2061-2099, it yields more than twice that of $H 612$.

\section{Potential yield-reducing mechanisms}

Evaluation of the stress parameters showed that under baseline management settings, maize does not face any significant water stress during 2020-2099 that could affect either photosynthesis, expansion, partitioning or development. On a scale from 0 (no stress) to 1 (maximum stress), values remained well below 0.02 for all climate change scenarios and the two future periods. Similar holds for excess water stress. While excess water stress was higher than water stress throughout the maize growing period, here too, values remained low with peaking at below 0.1 on the same scale.

Nitrogen stress gradually increased from 90 days after planting and reached a maximum level of 0.2 at 100 days after planting. Earlier in the growing period, nitrogen stress remained at a fraction of the peak value. 
Fig. 6 Mean yield deviation for maize (H612 cultivar) from dotted line) amongst the four adaptation treatments: deficit irrigation (DI), full irrigation (FI), mulch application(MU) and nitrogen fertilization $(15 \mathrm{~N})$, and unchanged management (NT) for 2020-2060 under the RCPs 2.6, 4.5 and 8.5; boxes represent mean and standard deviation, and vertical lines the minimum and maximum values; different letters indicate statistically significant yield deviations $(p<0.05)$ baseline yields (set to zero,

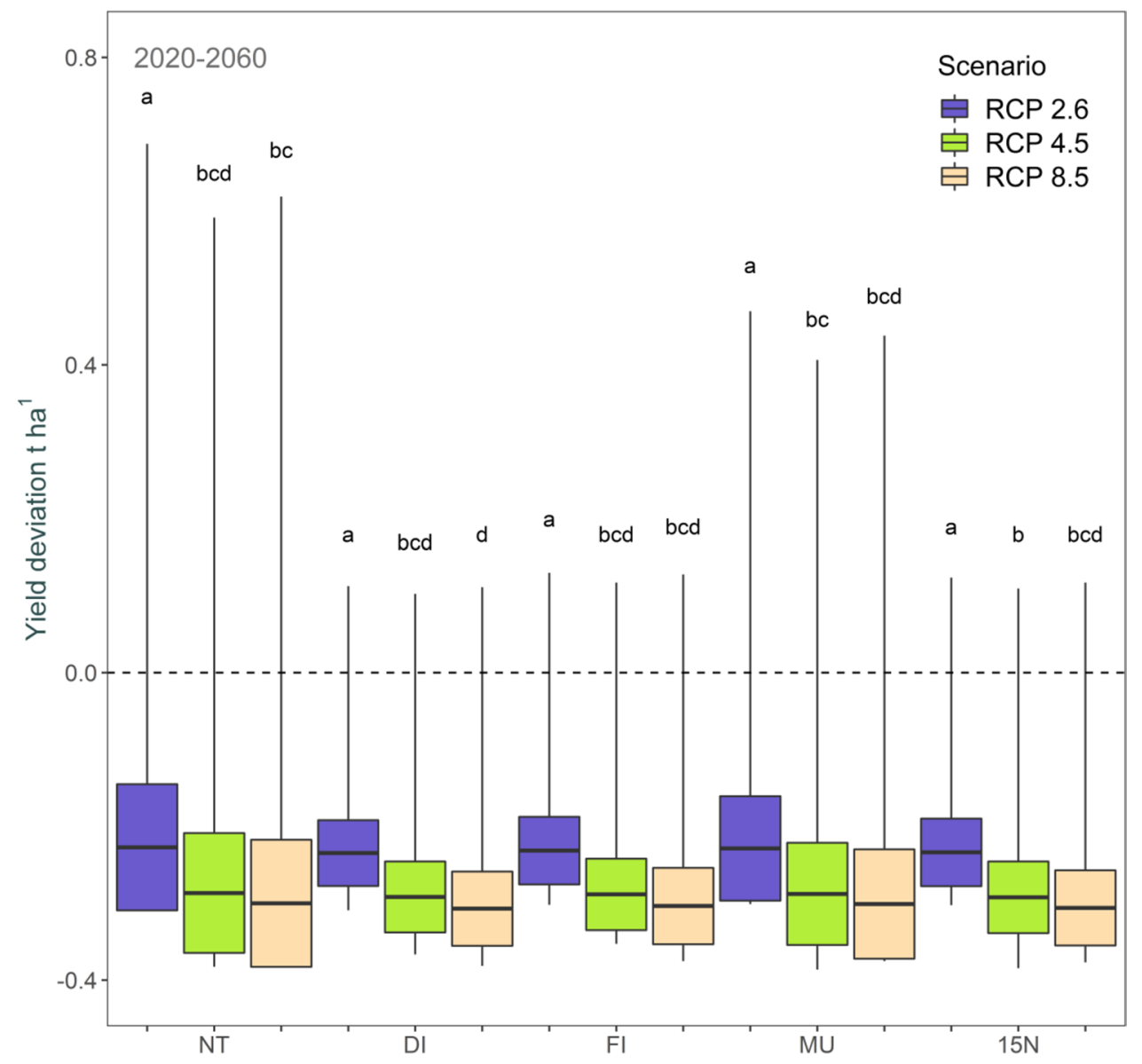

Fig. 7 Mean yields of $\mathrm{H6} 12$ and Situka cultivar for 2020-2060 and 2061-2099 under the RCPs 2.6, 4.5 and RCP 8.5 under baseline management; error bars indicate standard errors of yield estimates

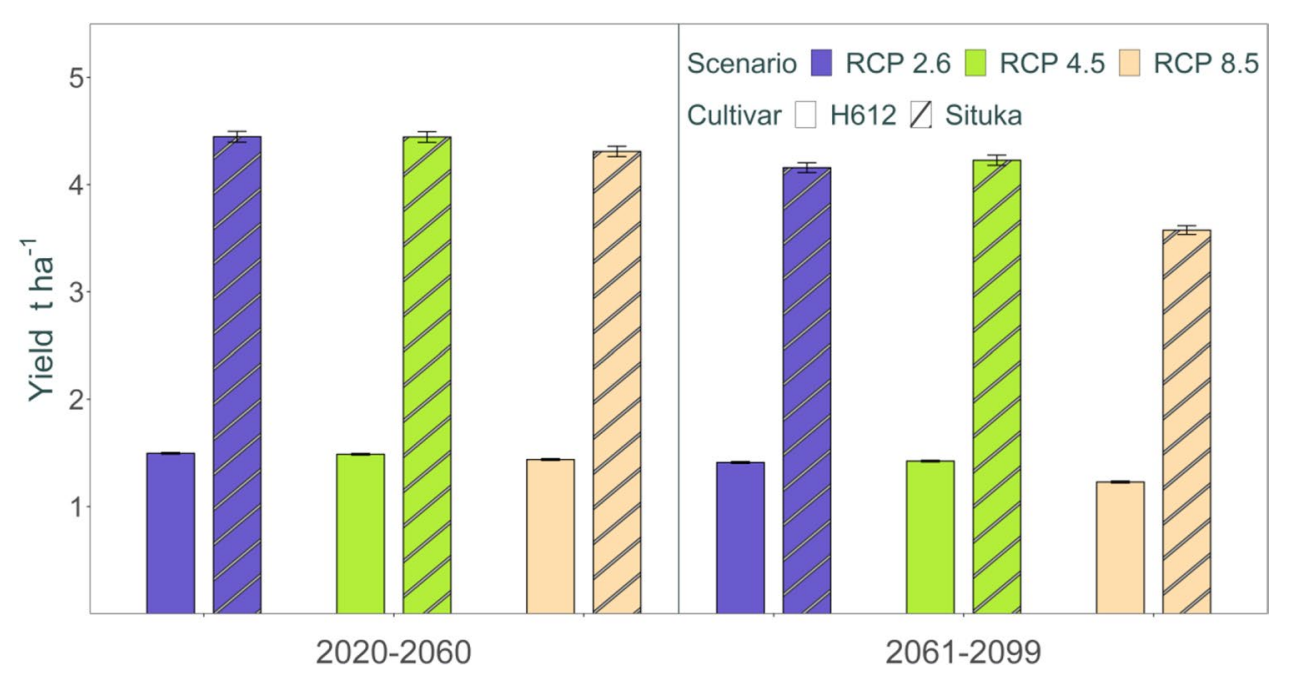

The number of days to harvest is projected to significantly decrease in the future time periods under all scenarios compared to the baseline (Fig. 8). While maize is harvested after an average of 76 days during 1980-2012, it will mature increasingly earlier during the 2020-2060 and the 2061-2099 period, and from RCP2.6 to RCP8.5 with the exception of RCP4.5 and 8.5 for 2020-2060.

\section{Discussion}

In this study, we were interested in assessing how future climate change will affect maize production in the Singida region of Tanzania, and which of selected crop 
Fig. 8 Mean days to harvest (DTH) for the 1980-2012 baseline and for 2020-2060 and 2061-2099 under the RCPs 2.6, 4.5 and 8.5 ; boxes represent mean and standard deviation, lines minimum and maximum values; different letters indicate statistically different days to harvest $(p<0.05)$

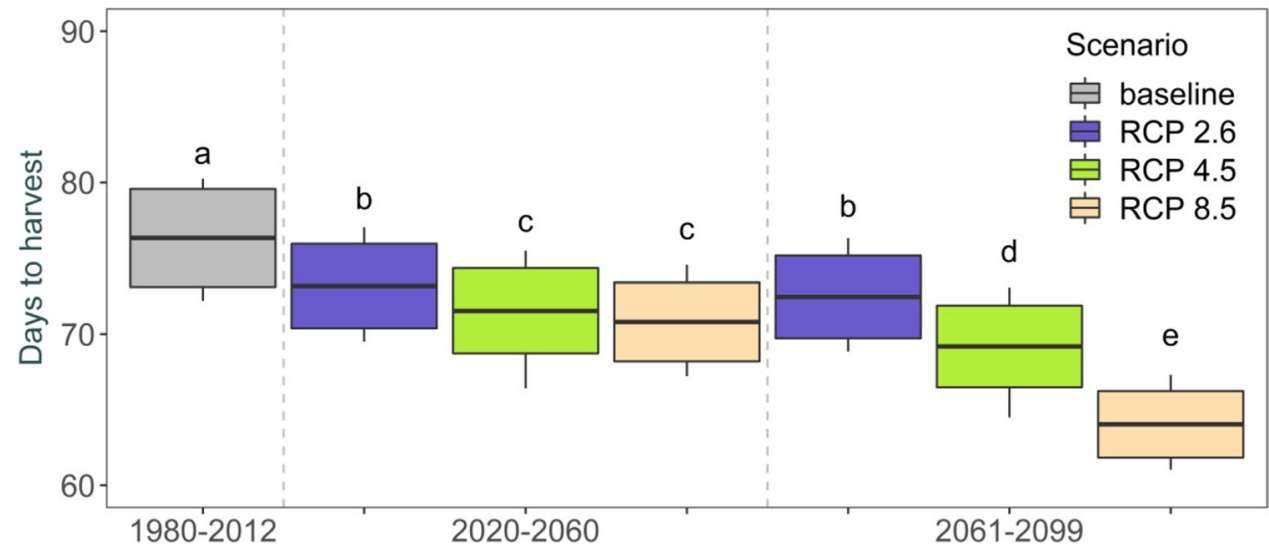

management and cultivar adaptation options will be effective for minimizing yield losses caused by climate change.

Simulated maize yields for the 1980-2012 baseline period of averaging $1.7 \mathrm{t} \mathrm{ha}^{-1}$ were comparable to measured yields of $1.6 \mathrm{t} \mathrm{ha}^{-1}$ reported for Singida between 2003 and 2010 (URT 2017c) while being slightly higher than the average of $1.1 \mathrm{t} \mathrm{ha}^{-1}$ reported in the agricultural basis data between 1996 and 2009 (URT 2004, 2005, 2010). This difference can be associated with the recycling of seeds, a common on-farm seed management practice leading to diminishing yield over time (Nkonya and Mwangi 2004; Japhether et al. 2006; Westengen et al. 2014) and this study's focus on the more productive northern part of the region.

The projected change in maize yields for Singida ranging between +21 and $-39 \%$ across all RCPs between 2060 and 2099 compares well with other findings. For example, Msongaleli et al. (2015) estimated a decline of -3.7 to $-25.3 \%$ for Tanzania, and Arndt et al. (2012) a deviation of +6 to $-37 \%$ for the region. On average, Singida maize yields declined by $16 \%$ in 2020-2060 and 20\% in 2061-2099 compared to the 1980-2012 baseline.

Surprisingly, none of the tested management adaptation options significantly reduced maize yield losses in future climate scenarios (cp. Figure 6). This indicates that growing conditions for maize in the study area are changing in a way that cannot be buffered either by irrigation, mulching or increased fertilization. As it is typical for the region however, rainfall did not change significantly. For example, projected monthly rainfall amounts throughout the maize growing period from October to May do not deviate significantly from those of the baseline, and while cumulative precipitation is generally increasing, the increase is only significant for RCP 8.5 in 2061-2099. This lack of significance for changes in cumulative rainfall in the future periods is in line with other findings in the region. While rainfall increase is generally expected in East Africa and Tanzania (e.g. Shongwe et al. 2011; Anyah and Qiu 2012; Arndt et al. 2012; Niang et al. 2014), contradictory results from single climate models are a prominent feature in climate projection studies for the region (e.g. Hulme et al. 2001; Agrawala et al. 2003; Warszwaski et al. 2014).

On the other hand, a significant increase in minimum and maximum temperatures is projected from all GCMs under all three RCPs. The increase of minimum and maximum temperatures from the baseline to the future periods with a mean of $1.3-4.0^{\circ} \mathrm{C}$ and $1.1-3.7^{\circ} \mathrm{C}$ (cp. Tab. 1) is within the range of other climate projection studies in Tanzania (Tumbo et al. 2010; Msongaleli et al. 2015). The higher average deviations of $\mathrm{T}_{\min }$ compared to those of $\mathrm{T}_{\max }$ may indicate a decrease in diurnal temperature ranges (DTR) (Washington and Pearce 2012), which are associated with minor positive benefits for maize yields though the underlying mechanisms are not well understood (Lobell 2007).

Therefore, the lack of a positive effect of significant increase in rainfall (RCP8.5 2061-2099) on maize yields and the absence of water stress suggest that changes in temperature must be the main drivers of the projected decline in future maize yields. Higher minimum temperatures lead to higher plant respiration rates during the night, which can negatively affect biomass accumulation and crop yields (Hatfield et al. 2011). High-temperature stress in maize occurs mostly at temperatures above 35 to $40{ }^{\circ} \mathrm{C}$ (Tiwari and Yadav 2019; EL Sabagh et al. 2020), values that are not projected to be reached in Singida region (cp. Figure 4). However, optimum temperatures for most of the maize growth and phenological stages, especially for grain filling, will still be exceeded (Sánchez et al. 2014). Furthermore, increased mean temperatures accelerate plant development, which was indicated by the consecutive decrease in the number of days to maturity from 76 days during the baseline period to 64 days in 2061-2099 for RCP8.5 (cp. Figure 8). The 76 days to maturity are already quite short when compared to other maize cultivars used in Tanzania (Mourice et al. 2014). Still, maize in the future periods is projected to mature even faster. Faster phenological development potentially influences maize grain yields in two ways: first, less time is available for the plant to develop optimal leaf area, which decreases the amount of radiation that can be 
intercepted, and the time of radiation interception is reduced due to the overall shortening of the duration of crop growth (Muchow et al. 1990); second, the reduced time available during the grain filling phase is decreasing the grain weight (Daynard et al. 1971). The decline in time to harvest therefore suggests that future maize yield in the study area will be limited by warmer temperatures, independent of effects of water availability (Harrison et al. 2011). It is therefore the temperature effect on maize growth and development that cannot be countered by an increase in irrigation, mulching or nitrogen fertilization.

In contrast to the tested management adaptation options that did not lead to any compensation of the projected negative future development of maize yields in the region, the simulations using the Situka cultivar (Fig. 7) show that there are significant differences in how well maize varieties are projected to perform under the described future climate conditions. Without going into detail about the traits which allow this particular cultivar to outperform $H 612$, our results confirm the important role genetic resources and seed systems play in adapting maize cultivation in Tanzania and other regions of sub-Saharan Africa to future climate change (Cairns et al. 2013; Westengen and Brysting 2014).

\section{Conclusion}

The development, implementation and adoption of suitable adaptation measures to address future maize yield losses from climate change are important for preserving economic development and food availability in sub-Saharan Africa. In this study from the semi-arid Singida region of Tanzania, our results indicate that adaptation measures like increased use of fertilizer, mulch and irrigation advocated by the Agricultural Sector Development Programme will not offset yield reductions caused by climate change. Future climate stress is set to reduce days to harvest, with consequences on maize physiological development and yields. However, maize yields improved using a different cultivar suggesting that this is a promising area for increasing adaptation in smallholder farming.

Thus, this study demonstrates that crop model simulations may reveal physiological and phenological mechanisms driving maize yields under different climate scenarios, knowledge useful for improving maize traits and assessing alternative adaptation measures. Amongst others, future research on maize adaptation in Singida might be focused on the traits of cultivars that have the potential to perform well in a warmer future, taking into account the complex nature of seed systems in the region, where the lines between formal and informal systems are blurred, and improved varieties are used alongside farm saved and recycled seeds.
Supplementary Information The online version contains supplementary material available at https://doi.org/10.1007/s10113-021-01812-z.

Funding Open Access funding enabled and organized by Projekt DEAL.

Open Access This article is licensed under a Creative Commons Attribution 4.0 International License, which permits use, sharing, adaptation, distribution and reproduction in any medium or format, as long as you give appropriate credit to the original author(s) and the source, provide a link to the Creative Commons licence, and indicate if changes were made. The images or other third party material in this article are included in the article's Creative Commons licence, unless indicated otherwise in a credit line to the material. If material is not included in the article's Creative Commons licence and your intended use is not permitted by statutory regulation or exceeds the permitted use, you will need to obtain permission directly from the copyright holder. To view a copy of this licence, visit http://creativecommons.org/licenses/by/4.0/.

\section{References}

Adhikari U, Nejadhashemi P, Woznicki SA (2015) Climate change and eastern Africa: a review of impact on major crops. Food Energy Secur 4:110-132. https://doi.org/10.1002/fes3.61

Agrawala S, Moehner A, Hemp A, Van Aalst M, Hitz S et al (2003) Development and climate change in Tanzania: focus on Mount Kilimanjaro. OECD. http://www.oecd.org/dataoecd/47/0/21058 838.pdf. Accessed 9 Feb 2018

Anyah RO, Qiu W (2012) Characteristic 20th and 21st century precipitation and temperature patterns and changes over the Greater Horn of Africa. Int J Climatol 32:347-363. https://doi.org/10. $1002 /$ joc. 2270

Arndt C, Farmer W, Strzepek K, Thurlow J (2012) Climate change, agriculture and food security in Tanzania. Rev Dev Econ 16:378393. https://doi.org/10.1111/j.1467-9361.2012.00669.x

Bahrenberg G, Giese E (1975) Statistische Methoden und ihre Anwendung in der Geographie. B.G. Teubner, Stuttgart

Basalirwa CPK, Odiyo JO, Mngodo RJ, Mpeta EJ (1999) The climatological regions of Tanzania based on the rainfall characteristics. Int J Climatol 19:69-80. https://doi.org/10.1002/(SICI)10970088(199901)19:1\%3c69::AID-JOC343\%3e3.0.CO;2-M

Bidogeza JC, Hoogenboom G, Berensten PBM, de Graaff J, Oude Lansink AGJM (2012) Application of DSSAT crop models to generate alternative production activities under combined use of organic-inorganic nutrients in Rwanda. J Crop Improv 26:346363. https://doi.org/10.1080/15427528.2011.641140

Brouwer C, Prins K, Heibloem M (1989) Irrigation water management. Irrigation scheduling. Training manual no. 4. Food and Agriculture Organization of the United Nations. Rome

Burney JA, Naylor RL, Postel SL (2013) The case for distributed irrigation as a development priority in sub-Saharan Africa. PNAS 110:12513-12517. https://doi.org/10.1073/pnas.1203597110

Cairns JE, Hellin J, Sonder K, Araus JL, MacRobert JF et al (2013) Adapting maize production to climate change in sub-Saharan Africa. Food Secur 5:345-360. https://doi.org/10.1007/ s12571-013-0256-x

Chorowicz J (2005) The East African rift system. J African Earth Sci 43:379-410. https://doi.org/10.1016/j.jafrearsci.2005.07.019

Comas LH, Trout TJ, DeJonge KC, Zhang H, Gleason SM (2019) Water productivity under strategic growth stage-based deficit irrigation in maize. Agric Water Manag 212:433-440. https:// doi.org/10.1016/j.agwat.2018.07.015 
Cooper PJM, Dimes J, Rao KPC, Shapiro B (2008) Coping better with current climatic variability in the rain-fed farming systems of sub-Saharan Africa : an essential first step in adapting to future climate change ? Agric Ecosyst Environ 126:24-35. https://doi. org/10.1016/j.agee.2008.01.007

Corbeels M, Chirat G, Messad S, Thierfelder C (2016) Performance and sensitivity of the DSSAT crop growth model in simulating maize yield under conservation agriculture. Eur J Agron 76:4153. https://doi.org/10.1016/j.eja.2016.02.001

Daynard TB, Tanner JW, Duncan WG (1971) Duration of the grain filling period and its relation to grain yield in corn, Zea mays L. 1. Crop Sci 11:45-48. https://doi.org/10.2135/cropsci1971. 0011183x001100010015x

Diao X, Hazell P, Thurlow J (2010) The role of agriculture in African development. World Dev 38:1375-1383. https://doi.org/10. 1016/j.worlddev.2009.06.011

Dijkshoorn K, van Engelen V (2003) Soil and terrain database for Southern Africa (SOTERSAF). ISRIC. www.isric.org. Accessed 15 Aug 2017

Dunne JP, John JG, Shevliakova E, Stouffer RJ, Krasting JP et al (2013) GFDL's ESM2 global coupled climate-carbon earth system models. Part II: Carbon System Formulation and Baseline Simulation Characteristics. J Clim 26:2247-2267. https://doi.org/10.1175/ JCLI-D-12-00150.1

EL Sabagh A, Hossain A, Aamir Iqbal M, Barutçular C, Islam MS et al (2020) Maize adaptability to heat stress under changing climate. In: Plant Stress Physiology. IntechOpen, pp 1-24

Eyshi Rezaei E, Gaiser T (2017) ZEF-discussion papers on development policy No. 239 change in crop management strategies could double the maize yield in Africa

Ezekiel O, Igbadun HE (2018) Water productivity of a maize crop under deficit irrigation scheduling using gravity drip system. PAT 12:161-172. https://doi.org/10.13140/RG.2.2.11547.77608

Fischer G, Shah M, Tubiello NF, van Velhuizen H (2005) Socioeconomic and climate change impacts on agriculture. An integrated assessment, 1990-2080. Philos Trans R Soc B Biol Sci 360:2067-2083. https://doi.org/10.1098/rstb.2005.1744

Food and Agriculture Organization of the United Nations (FAO) (eds) (2006) Food security and agricultural development in sub-Saharan Africa. FAO. http://www.fao.org/3/a-a0788e.pdf. Accessed 9 Feb 2018

Food and Agriculture Organization of the United Nations (FAO) (eds) (2015) World reference base for soil resources 2014. International soil classification system for naming soils and creating legends for soil maps. FAO. http://www.fao.org/3/a-i3794e.pdf. Accessed 9 Feb 2018

Gowing JW, Young MDB, Hatibu N, Mahoo HF, Rwehumbiza F et al (2003) Developing improved dryland cropping systems for maize in semi-arid Tanzania. Part II. Use of a model to extrapolate and add value to experimental results. Exp Agric 39:293-306. https:// doi.org/10.1017/S0014479703001297

Greaves GE, Wang YM (2017) Identifying irrigation strategies for improved agricultural water productivity in irrigated maize production through crop simulation modelling. Sustainability 9:17. https://doi.org/10.3390/su9040630

Gude VK (2016) Simulation of agronomic practices for Southern Highlands of Tanzania using DSSAT CERES-maize model. In: Direk M (ed) 3rd International Conference on Sustainable Agriculture and Environment. Proceedings Book. Warsaw, pp 527-531

Han E, Ines A, Koo J (2015) Global high-resolution soil profile database for crop modelling applications. Harvard Dataverse. https:// doi.org/10.7910/DVN/1PEEY0.Accessed14Aug2017

Harrison L, Michaelsen J, Funk C, Husak G (2011) Effects of temperature changes on maize production in Mozambique. Clim Res 46:211-222. https://doi.org/10.3354/cr00979
Hatfield JL, Boote KJ, Kimball BA, Ziska LH, Izaurralde RC et al (2011) Climate impacts on agriculture: implications for crop production. Agron J 103:351-370. https://doi.org/10.2134/agron j2010.0303

Hecklau HK (1978) Agrargeographie Ostafrika. Kenya, Uganda, Tanzania. Borntraeger, Berlin

Hempel S, Frieler K, Warszawski L, Schewe J, Piontek F (2013) Bias corrected GCM input data for ISI-MIP fast track. GFZ Data Service. https://doi.org/10.5880/PIK.2016.001.Accessed14Aug2017

Hillocks RJ (2014) Addressing the yield gap in Sub-Saharan Africa. Outlook Agric 43:85-90. https://doi.org/10.5367/oa.2014.0163

Hoogenboom G, Porter CH, Shelia V, Boote KJ, Singh U et al (2017) Decision support system for agrotechnology transfer (DSSAT) version 4.7 (www.DSSAT.net). DSSAT Found

Hourdin F, Foujols M-A, Codron F, Guemas V, Dufresne J-L et al (2013) Impact of the LMDZ atmospheric grid configuration on the climate and sensitivity of the IPSL-CM5A coupled model. Clim Dyn 40:2167-2192. https://doi.org/10.1007/ s00382-012-1411-3

Hulme M, Doherty R, Ngara T, New M, Lister D (2001) African climate change: 1900-2100. Clim Res 17:145-168. https://doi.org/ $10.3354 / \mathrm{cr} 017145$

Igbadun HE, Salim BA, Tarimo AKPR, Mahoo HF (2008) Effects of deficit irrigation scheduling on yields and soil water balance of irrigated maize. Irrig Sci 27:11-23. https://doi.org/10.1007/ s00271-008-0117-0

Iversen T, Bentsen M, Bethke I, Debernard JB, Kirkevåg A et al (2013) The Norwegian earth system model, NorESM1-M - Part 2: Climate response and scenario projections. Geosci Model Dev 6:389-415. https://doi.org/10.5194/gmdd-5-2933-2012

Japhether W, Groote HDE, Lawrence M, Kengo D, Mohammed L (2006) Recycling hybrid maize varieties : is it backward practice or innovative response to adverse conditions in Kenya? Int Assoc Agric Econ Conf 18 Annual Meeting Queensland, Australia. https://doi.org/10.22004/ag.econ.25726

Johnson CW, Byergo KM, Fleuret P, Simmons E, Wasserman G (1980) A.I.D. project impact evaluation report 2. Kitale maize: limites of success. Agency for International Development

Jones CA, Kiniry JR, Dyke PT (1986) CERES-Maize : a simulation model of maize growth and development. Texas A \& M University Press, Texas

Jones CD, Hughes JK, Bellouin N, Hardiman SC, Jones GS et al (2011) The HadGEM2-ES implementation of CMIP5 centennial simulations. Geosci Model Dev 4:543-570. https://doi.org/10.5194/ gmd-4-543-2011

Jones JW, Hoogenboom G, Porter CH, Boote KJ, Batchelor WD et al (2003) The DSSAT cropping system model. Eur J Agron 18:235265. https://doi.org/10.1016/s1161-0301(02)00107-7

Lana MA, Vasconcelos ACF, Gornott C, Schaffert A, Bonatti M et al (2017) Is dry soil planting an adaptation strategy for maize cultivation in semi-arid Tanzania? Food Secur. https://doi.org/10. 1007/s12571-017-0742-7

Lema MA, Majule AE (2009) Impacts of Climate change, variability and adaptation strategies on agriculture in semi arid areas of Tanzania. The case of Manyoni District in Singida Region, Tanzania. Afr J Environ Sci Technol 3:206-218. https://doi.org/10. 5897/AJEST09.099

Liu DL, Zeleke KT, Wang B, Macadam I, Scott F et al (2017) Crop residue incorporation can mitigate negative climate change impacts on crop yield and improve water use efficiency in a semiarid environment. Eur J Agron 85:51-68. https://doi.org/10.1016/j. eja.2017.02.004

Lobell DB (2007) Changes in diurnal temperature range and national cereal yields. Agric for Meteorol 145:229-238. https://doi.org/ 10.1016/j.agrformet.2007.05.002 
Luhunga PM (2017) Assessment of the impacts of climate change on maize production in the southern and western highlands sub-agro ecological zones of Tanzania. Front Environ Sci 5:1-16. https:// doi.org/10.3389/fenvs.2017.00051

Macauley H, Ramadjita T (2015) An action plan for African agricultural transformation. Cereal crops: rice, maize, millet, sorghum, wheat. AFDB. https://www.afdb.org/fileadmin/uploads/ afdb/Documents/Events/DakAgri2015/Cereal_Crops-_Rice_ Maize_Millet_Sorghum_Wheat.pdf. Accessed 13 Feb 2018

Mfwango LH, Tripathi SK, Pranuthi G, Dubey SK, Gubey VK (2018) Application of decision support system for agro technology transfer (DSSAT) to simulate agronomic practices for cultivation of maize in southern highland of Tanzania. Agric Sci 09:910 923. https://doi.org/10.4236/as.2018.97063

Moradi R, Koocheki A, Nassiri Mahallati M, Mansoori H (2013) Adaptation strategies for maize cultivation under climate change in Iran: irrigation and planting date management. Mitig Adapt Strateg Glob Chang 18:265-284. https://doi.org/10.1007/ s11027-012-9410-6

Moss RH, Edmonds JA, Hibbard KA, Manning MR, Rose SK et al (2010) The next generation of scenarios for climate change research and assessment. Nature 463:747-756. https://doi.org/ 10.1038 /nature 08823

Mourice SK, Rweyemamu CL, Tumbo SD, Amuri N (2014) Maize cultivar specific parameters for decision support system for agrotechnology transfer (DSSAT) application in Tanzania. Am J Plant Sci 5:821-833. https://doi.org/10.4236/ajps.2014.56096

Msongaleli BM, Rwehumbiza F, Tumbo SD, Kihupi N (2015) Impacts of climate variability and change on rainfed sorghum and maize: implications for food security policy in Tanzania. J Agric Sci 7:124-142. https://doi.org/10.5539/jas.v7n5p124

Muchow RC, Sinclair TR, Bennett JM (1990) Temperature and solar radiation effects on potential maize yield across locations. Agron J 82:338-343. https://doi.org/10.2134/agronj1990.0002196200 $8200020033 x$

Murthy VRK (2004) Crop growth modeling and its applications in agricultural meteorology. WMO. http://www.wmo.int/pages/prog/ wcp/agm/publications/AGM8_en.php. Accessed 13 Feb 2018

Niang I, Ruppel OC, Abdrabo MA, Essel A, Lennard C et al (2014) Africa. In: Climate change 2014: impacts, adaptation, and vulnerability. Part B: Regional Aspects. Contribution of Working Group II to the Fifth Assessment Report of the Intergovernmental Panel on Climate Change [Barros VR, Field CB, Dokken DJ, Mastrandrea MD, Mach KJ, Bilir TE, Chatterjee M, Ebi KL, Estrada YO, Genova RC, Girma B, Kissel ES, Levy AN, MacCracken S, Mastrandrea PR, White LL (eds.)]. Cambridge University Press, Cambridge, and New York, pp 1199-1265

Nkonya E, Mwangi W (2004) The economic rationale of recycling hybrid seeds in Northern Tanzania. EAJRD 20:113-124. https:// doi.org/10.4314/eajrd.v20i1.28358

Organisation for Economic Co-operation and Development / Food and Agriculture Organization of the United Nations (OECD/FAO) (eds) (2016) Agriculture in Sub-Saharan Africa. Prospects and challenges for the next decade. In: OECD/FAO (eds) Agricultural Outlook 2016-2025. OECD Publishing, Paris, pp 59-93

Pachauri R, Meyer E (eds) (2014) Climate change 2014: Synthesis report. Contribution of Working Groups I, II and III to the Fifth Assessment Report of the Intergovernmental Panel on Climate Change. IPCC, Geneva, p 151

Pauw K, Thurlow J (2011) Agricultural growth, poverty, and nutrition in Tanzania. Food Policy 36:795-804. https://doi.org/10.1016/j. foodpol.2011.09.002

Qin W, Hu C, Oenema O (2015) Soil mulching significantly enhances yields and water and nitrogen use efficiencies of maize and wheat: a meta-analysis. Sci Rep 5:1-13. https://doi.org/10. 1038/srep16210
R Core Team (2017) A language environment for statistical computing. R. http://www.r-project.org/about.html. Accessed 25 Jun 2017

Randall DA, Wood RA, Bony S, Colman R, Fichefet T et al (2007) Cilmate models and their evaluation. In: Climate Change 2007: The Physical Science Basis. Contribution of Working Group I to the Fourth Assessment Report of the Intergovernmental Panel on Climate Change [Solomon S, Qin D, Manning M, Chen Z, Marquis M, Averyt KB, Tignor M, Miller HL (eds.)]. Cambridge University Press, Cambridge, and New York

Rao KPC, Sridhar G, Mulwa RM, Kilavi MN, Esilabla A et al (2015) Impacts of climate variability and change on agricultural systems in East Africa. In: Hillel D, Rosenzweig C (eds) Handbook of climate change and agroecosystems. The Agricultural model intercomparison and improvement project. Integrated crop and economic assessment. Part 2. Imperial College Press, London, pp 75-124

Rasch B, Hofmann W, Friese M, Naumann E (2010) Quantitative Methoden 1. Einführung in die Statistik für Psychologen und Sozialwissenschaftler, 3rd edn. Springer, Berlin. Heidelberg

Regional Center for Mapping of Resources for Development (RCMRD) (2015) Tanzania land cover 2010. Scheme II. RCMRD. http:// servirportal.rcmrd.org/layers/servir\%3Atanzania_landcover_ 2010_scheme_ii. Accessed 19 Jun 2017

Rowhani P, Lobell DB, Linderman M, Ramankutty N (2011) Climate variability and crop production in Tanzania. Agric for Meteorol 151:449-460. https://doi.org/10.1016/j.agrformet.2010.12.002

Sánchez B, Rasmussen A, Porter JR (2014) Temperatures and the growth and development of maize and rice: a review. Glob Chang Biol 20:408-417. https://doi.org/10.1111/gcb.12389

Saseendran SA, Ahuja LR, Nielsen DC, Trout TJ, Ma L (2008) Use of crop simulation models to evaluate limited irrigation management options for corn in a semiarid environment. Water Resour Res 44 https://doi.org/10.1029/2007WR006181

Sepaskhah AR, Afshar-Chamanabad H (2002) Determination of infiltration rate for every-other furrow irrigation. Biosyst Eng 82:479-484. https://doi.org/10.1006/bioe.2002.0088

Shapiro SS, Wilk MB (1965) An analysis of variance test for normality. Complete Samples Biometrika Trust 52:591-611. https://doi.org/ $10.2307 / 2333709$

Sharda V, Gowda PH, Marek G, Kisekka I, Ray C et al (2019) Simulating the impacts of irrigation levels on soybean production in Texas high plains to manage diminishing groundwater levels. J Am Water Resour Assoc 55:56-69. https://doi.org/10.1111/ 1752-1688.12720

Shemdoe RS, Van Damme P, Kikula IS (2009) Increasing crop yield in water scarce environments using locally available materials: an experience from semi-arid areas in Mpwapwa District, central Tanzania. Agric Water Manag 96:963-968. https://doi.org/10. 1016/j.agwat.2009.01.007

Shetto R, Owenya M (2007) Conservation agriculture as practised in Tanzani. Conservation agriculture in Africa series. African Conservation Tillage Network, Centre de Coopération Internationale de Recherche Agronomique pour le Développement, Food and Agriculture Organization of the United Nations. Nairobi

Shongwe ME, van Oldenborgh GJ, van den Hurk B, van Aalst M (2011) Projected changes in mean and extreme precipitation in Africa under global warming Part II: East Africa. J Clim 24:3718-3733. https://doi.org/10.1175/2010JCLI2883.1

The United Republic of Tanzania (URT) (eds) (2004) Agricultural basic data 1996/76-2002/03/04. URT. http://www.kilimo.go. tz/index.php/en/resources/category/statistics/P10. Accessed 17 Jan 2017

The United Republic of Tanzania (URT) (eds) (2005) Agricultural basic data 1998/1999 - 2004/2005. URT. http://www.kilimo.go. 
tz/index.php/en/resources/category/statistics. Accessed 17 Nov 2017

The United Republic of Tanzania (URT) (eds) (2006) Soils of Tanzania and their potential for agricultural development. Draft Report. URT. www.kilimo.go.tz/maps/Soils_of_Tanzania.doc. Accessed 13 Feb 2018

The United Republic of Tanzania (URT) (eds) (2010) Agricultural basic data 2005/2006-2009/2010. URT. http://www. kilimo.go.tz/index.php/en/resources/view/ agriculture-basicdata-2005-2006-2009-2010. Accessed 17 Nov 2017

The United Republic of Tanzania (URT) (eds) (2012) National sample census of agriculture 2007/2008. Volume Vm. Regional report Singida Region. URT. http://harvestchoice.org/sites/default/ files/downloads/publications/Tanzania_2007-8_Vol_5m.pdf. Accessed 13 Feb 2018

The United Republic of Tanzania (URT) (eds) (2015) Intended Nationally Determed Contributions (INDCs). Second National Communication Report. http:// https://www4.unfccc.int/sites/ndcstaging/ PublishedDocuments/The\%20United\%20Republic\%20of\%20Tan zania\%20First $\% 20$ NDC/The $\% 20$ United $\% 20$ Republic $\% 20$ of $\%$ 20Tanzania\%20First\%20NDC.pdf. Accessed 13 Feb 2018

The United Republic of Tanzania (URT) (eds) (2016) 2014 / 15 annual agricultural sample survey report. URT. http:// https://www.nbs. go.tz/nbs/takwimu/Agriculture/Annual_Agricultural_Sample_ Survey_Report2014_15.pdf. Accessed 13 Feb 2018

The United Republic of Tanzania (URT) (eds) (2017a) Agricultural sector development progamme phase II (ASDP II). http://www. kilimo.go.tz/index.php/en/resources/view/agricultural-sectordevelopment-programme-phase-ii-asdp-ii. Accessed 18 Mar 2019. https://www.nbs.go.tz/nbs/takwimu/Agriculture/Annual_ Agricultural_Sample_Survey_Report2014_15.pdf. Accessed 13 Feb 2018

The United Republic of Tanzania (URT) (eds) (2017b) Climate-smart agriculture guideline. http://www.kilimo.go.tz/uploads/regul ations/National_CSA_Guideline.pdf. Accessed 15 Mar 2020

The United Republic of Tanzania (URT) (eds) (2017c) Farm yield data Singida region. Accessed 13 Feb 2018

The United Republic of Tanzania (URT) (eds) (2017d) Singida socioeconomic profile, 2015. http://www.singida.go.tz/storage/app/ uploads/public/59a/431/dc1/59a431dc167e2754571355.pdf. Accessed 15 Mar 2020

The World Bank (2018) Agriculture, value added. The World Bank. https://data. worldbank.org/indicator/NV.AGR.TOTL.ZS. Accessed 13 Feb 2018

Thorburn PJ, Boote KJ, Hargreaves JNG, Poulton PL, Jones JW (2015) A new protocol-driven approach for regional integrated assessments. In: Hillel D, Rosenzweig C (eds) Handbook of climate change and agroecosystems. The Agricultural model intercomparison and improvement project. Integrated crop and economic assessment. Part 1. Imperial College Press, London, pp 79-99

Thornton PK, Jones PG, Alagarswamy G, Andresen J, Herrero M (2010) Adapting to climate change. Agricultural system and household impacts in East Africa. Agric Syst 103:73-82. https:// doi.org/10.1016/j.agsy.2009.09.003

Thurlow J, Wobst P (2003) Poverty-focused social accounting matrices for Tanzania. IFPRI. http://www.ifpri.org/publication/pover ty-focused-social-accounting-matrices-tanzania. Accessed 13 Feb 2018
Tiwari YK, Yadav SK (2019) High temperature stress tolerance in maize (Zea mays L.): physiological and molecular mechanisms. J Plant Biol 62:93-102. https://doi.org/10.1007/ s12374-018-0350-x

Tumbo SD, Mpeta E, Tadross M, Kahimba FC, Mbillinyi BP et al (2010) Application of self-organizing maps technique in downscaling GCMs climate change projections for Same, Tanzania. Phys Chem Earth 35:608-617. https://doi.org/10.1016/j.pce. 2010.07.023

United Nations Framework Convention on Climate Chnage (UNFCCC) (2019) United Nations Climate Change Annual Report 2018. Bonn

United States Agency for International Development (USAID) (eds) (2010) Staple food value chain analysis. Country report Tanzania. USAID. http://pdf.usaid.gov/pdf_docs/pa00jxx8.pdf. Accessed 13 Feb 2018

Warszwaski L, Frieler K, Huber V, Piontek F, Serdeczny O et al (2014) The inter-sectoral impact model intercomparison project (ISIMIP). Project framework. Proc Natl Acad Sci U S A 111:32283232. https://doi.org/10.1073/pnas.1312330110

Washington R, Pearce H (2012) Climate change in east African agriculture: recent trends, current projections, crop-climate suitability, and prospects for improved climate model information. CCAFS. https://assets.publishing.service.gov.uk/media/57a08aae40f0b65 2dd000846/Crop_Climate_Model_Information_3_EastAfrica. pdf. Accessed 13 Feb 2018

Watanabe S, Hajima T, Sudo K, Nagashima T, Takemura T et al (2011) MIROC-ESM 2010: model description and basic results of CMIP5-20c3m experiments. Geosci Model Dev 4:845-872. https://doi.org/10.5194/gmd-4-845-2011

Weedon GP, Balsamo G, Bellouin N, Gomes S, Best MJ et al (2014) The WFDEI meteorological forcing data set: WATCH Forcing data methodology applied to ERA-Interim reanalysis data. Water Resour Res 50:7505-7514. https://doi.org/10.1002/2014WR0156 38

Welch BL (1938) The significance of the difference between two means when the population variances are unequal. Biometrika 29:350362. https://doi.org/10.1093/biomet/29.3-4.350

Westengen OT, Brysting AK (2014) Crop adaptation to climate change in the semi-arid zone in Tanzania: the role of genetic resources and seed systems. Agric Food Secur 3:3. https://doi.org/10.1186/ 2048-7010-3-3

Westengen OT, Ring KH, Berg PR, Brysting AK (2014) Modern maize varieties going local in the semi-arid zone in Tanzania. BMC Evol Biol 14:1-12. https://doi.org/10.1186/1471-2148-14-1

Zech W, Schad P, Hintermaier-Erhard G (2014) Böden der Welt. Ein Bildatlas, 2nd edn. Springer, Berlin. Heidelberg

Zimmermann-Janschitz S (2014) Statistik in der Geographie. Eine Exkursion durch die desktiptive Statistik. Springer, Berlin. Heidelberg

Publisher's note Springer Nature remains neutral with regard to jurisdictional claims in published maps and institutional affiliations. 